\title{
Suatu Telaah Budaya: Agama dalam Kehidupan Orang Jepang
}

\author{
Sandra Herlina \\ Program Studi Sastra Jepang, Fakultas Sastra, \\ Universitas Al Azhar Indonesia, Jl. Sisingamangaraja, Jakarta 12110 \\ E-mail: $\underline{\text { sandra@uai.ac.id }}$
}

\begin{abstract}
Abstrak - Pandangan orang Jepang terhadap agama adalah sebagai ikatan budaya dan tradisi. Memiliki dua atau lebih agama dalam kehidupan seseorang adalah sesuatu yang wajar, dan hal tersebut menjadikan salah satu karakteristik agama Jepang. Dalam sejarahnya yang panjang, agama telah mengalami perkembangan, agama asli tetap dipertahankan walaupun muncul agama-agama baru, agama asli tetap hidup dengan harmonis meskipun terjadi sinkretisme. Ada beberapa agama yang ada di Jepang selain Shinto sebagai folk belieft dan sebagai kepercayaan, antara lain Budha, agama-agama Samawi, Shinshukyo dan agamaagama lainnya yang berdampingan secara harmonis. Meskipun dikatakan bahwa agama tidak penting dalam kehidupan orang Jepang, namun pada kenyataannya orang Jepang tetap meneruskan kehidupan keagamaan dalam perilaku mereka sebagai "penjaga tradisi" kebudayaan mereka.
\end{abstract}

Abstract - The Japanese view of religion as cultural ties and traditions. Having two or more religion in one's life is something that is reasonable and that is became one of Japanese religion character. In its long history, religions have experienced growth, the original religion live harmony is maintained despite an emerging syncretism or religious. There are some religions that exist in Japan other than folk belieft Shinto as the belief among others, Buddhist, Samawi religions, Shinshukyo and others who live together in harmony. Although it is said that religion is not important in Japanese life, but in fact the Japanese continue to run as part of religious life in their behavior as culture "guardians of tradition"

Keywords - Japanese religion, culture

\section{PENDAHULUAN}

Sekarang ini, Jepang diakui sebagai salah satu Negara maju di dunia. Seperti apakah bangsa Jepang sehingga dapat membawa negaranya menjadi salah satu negara maju di dunia dan bagaimana pula kebudayaan bangsa ini? Saya pikir masalah ini cukup banyak menarik minat penelitipeneliti asing untuk menoleh dan meneliti Jepang .

Adapun yang dimaksud dengan kebudayaan ${ }^{1}$ adalah, kebudayaan dapat diartikan sebagai suatu fenomena sosial dan tidak dapat dilepaskan dari perilaku dan tindakan warga masyarakat yang mendukung atau menghayatinya. Sebaliknya, keteraturan, pola, atau konfigurasi yang tampak pada perilaku dan tindakan warga suatu masyarakat tertentu dibandingkan perilaku dan tindakan warga masyarakat yang lain, tidaklah dapat dipahami tanpa dikaitkan dengan kebudayaan masyarakat tersebut.

Pada prinsipnya kehidupan beragama adalah kepercayaan terhadap keyakinan adanya kekuatan gaib. Supernatural yang memiliki pengaruh bagi kehidupan individu, kelompok masyarakat atau yang lainnya. Beragama sebagai fenomena universal kehidupan manusia yang seperti yang dikatakan oleh Bergson (1859-1941), seorang filsuf Perancis bahwa kita dapat menemukan masyarakat tanpa sains, seni dan filsafat namun tidak ada masyarakat tanpa agama. Sementara itu seorang filsuf Norbeck (1974:3) mengatakan bahwa ia tidak mengakui adanya beragama universal dalam kehidupan individual. Individu-individu yang non religius menurutnya makin umum di kalangan masyarakat modern, namun kepercayaan terhadap keagamaan tetap saja dipegang oleh semua masyarakat.

${ }^{1}$ Sutrisno Mudji Ed.all., 2005 
Sehubungan dengan kehadiran agama di Jepang, seorang peneliti keagamaan Miyake Hitoshi ${ }^{2}$ dalam bukunya Nihon shukyo No Kozo 日本宗教の構造 menjelaskan mengenai agama di dunia yang berhubungan dengan agama di Jepang menjadi beberapa kategori sebagai berikut:

1) Mikai Shukyou, Agama Primitif. Penganutnya belum bisa baca dan tulis, contoh: animisme, kepercayaan terhadap roh dan dan gejala-gejala alam; totemisme (animal worship) adalah keyakinan bahwa manusia memiliki hubungan dengan binatang; shamanisme, agama yang mempercayai ada kekuatan dukun; shijo shinshinko, agama yang percaya bahwa yang diyakini dan dipercayai hidup di langit.

2) Minzoku Shukyo yaitu agama rakyat atau agama negara yang hanya ada dalam satu bangsa saja, contoh: Shinto, Tao, Yahudi dan lainnya.

3) Fuhen Shukyou yaitu agama-agama universal atau agama samawi, agama-agama yang dapat ditemukan dimana saja, contoh: Islam, Kristen, Budha dan lainnya.

Adapun dalam kehidupan keseharian orang Jepang nampaknya agama bukanlah hal yang dianggap penting. Masyarakat Jepang mempunyai pandangan yang sangat sekuler dan tidak begitu peduli pada agama. Hal ini dapat dilihat dari jumlah penganut agama di Jepang dari data yang dikeluarkan dan direvisi oleh Kementrian Pendidikan Jepang barubaru ini sebagai berikut, penganut Shinto berkisar 107 juta orang, Budha berkisar 89 juta orang, Katolik dan Kristen Protestan sekitar 3 juta orang, serta sekitar 10 juta orang sebagai penganut agama lain-lain. Apabila dijumlahkan maka total seluruh penganut agama di Jepang akan berjumlah 290 juta. Ditambah dengan jumlah penganut berbagai aliran dari Budha dan Shinto saja hampir melebihi 200 juta orang. Dengan demikian penganut agama di Jepang berjumlah dua kali lipat dari jumlah penduduknya. Total penganut agama di Jepang melebihi jumlah penduduk ini diperoleh dari data yang dikumpulkan berdasarkan angket yang diambil dari berbagai organisasi keagamaan di seluruh Jepang dengan cara melihat tradisi beragamaan orang Jepang. Pada umumnya orang Jepang menganut lebih dari satu agama (double faith).

Pada umumnya orang Jepang ketika lahir mendapatkan upacara dalam Shinto, dan diikuti dengan berbagai upacara keagamaan dan ritual

\footnotetext{
${ }^{2}$ Hitoshi Miyake
}

lainnya sepanjang hidupnya, ketika menikah dalam Shinto atau Kristen dan dalam upacara Budha pada kematian dan penghormatan terhadap leluhur. Selain Buddha dan Shinto, alasan apakah yang menyebabkan orang Jepang memeluk lebih dari satu agama? Hal ini mungkin sulit untuk dijelaskan. Meminjam pendapat dari seorang peneliti agamaagama di Jepang, Prof.Hanazono Toshimaro dari Universitas Tohoku yang mengatakan bahwa Jepang diibaratkan sebagai "musium agama-agama di dunia". Mungkin pernyataan tersebut diatas terlalu dilebih-lebihkan namun banyak peneliti yang berangapan demikian karena pada umumnya orang Jepang tidak percaya pada agama namun pada kenyataannya mereka menganut atau memeluk lebih dari satu agama.

Konon agama asli orang Jepang adalah Shinto (神道) yang artinya “jalan para dewa“. Setelah masuknya Budha melalui China dan Korea sekitar abad ke 6, melalui pergulatan yang panjang, terjadi interaksi yang serasi antara dewa-dewa Shinto dengan Budha yang dikenal dengan 本地垂迹 honji suijaku. Pada umumnya sekarang ini orang Jepang tidak ada yang hanya beragama Shinto atau Budha saja bahkan ditambah dengan Kristen atau dengan yang lainnya. Mereka meletakan prioritas-prioritas atau kebutuhan untuk pada masing-masing agama. Demikian pula sampai saat ini di rumah-rumah orang Jepang, utamanya di wilayah pedesaan terdapat altar Shinto dan Budha juga adakalanya ada patung Bunda Maria. Mereka juga pergi ke Jinja atau kuil Shinto dan pergi ke Otera atau kuil Budha mungkin juga pergi ke gereja atau kegiatan keagamaan lainnya sesuai dengan keinginan dan kebutuhan mereka.

Agama Kristen Katolik untuk pertama kalinya diperkenalkan di Jepang pada pertengahan abad 15 yang dibawa oleh para misionaris dari Portugis dan Spanyol antara lain dari Franciscus Xavier. Dalam waktu yang amat singkat agama Kristen dapat menyebar di kalangan penguasa militer karena mereka mengunakan Kristen atau budaya Barat terutama teknologinya untuk kepentingan Perang atau untuk politisasi pemerintahan, namun seabad kemudian agama ini dilarang karena Kristen dianggap berbahaya untuk pemerintah saat itu. Dapat dikatakan bahwa Kristen tidak memiliki pengaruh yang kuat dalam kebudayaan Jepang hingga kini. Kemungkinan adanya unsur monotheisme dalam agama ini sehingga susah diterima atau diasimilasikan ke dalam kebudayaan Jepang. Kemungkinan juga peraturan yang cukup 
keras dalam Kristen juga menghambat penyebaran dan pengembangan Kristen sebagai agama karena dianggap tidak cocok dengan aturan temparamen orang Jepang, yang boleh minuman keras, memperbolehkan praktek sex bebas dan juga halhal yang sifatnya duniawi asal kesemuanya ini dilakukan tidak mengganggu lingkungan. Monoteistik yang ada dalam Kristen khususnya dan juga agama-agama samawi lainnya menghalangi perkembangan agama tersebut. Dalam kehidupan orang Jepang dapat menerima dewadewa yang begitu banyak dan juga memiliki berbagai fungsinya. Kesemua itu orang Jepang bisa menerimanya tanpa bingung atau perasaan bertentangan. Karena orang Jepang, secara tradisional Shinto memusatkan pada kesejahteraan kelompok sedangkan Budha memperperhatikan kesejahteraan keluarga. Kristen hanya hadir dalam kehidupan individu-individu perkotaan serta suasana kehidupan industri modern dan juga gaya hidup.

Bagi orang Jepang semua fenomena alam yang hidup atau dianggap hidup (animate) maupun yang tidak hidup (inanimate) bahkan benda buatan manusiapun akan dianggap memiliki potensi untuk dianggap hidup apabila mereka yakini ada kekuatan gaib di benda-benda tersebut. Hal-hal inilah yang dikenal dengan folk belieft. Mengenai hal ini Harumi Befu mengatakan bahwa memang rakyat Jepang di dalam kepercayaan rakyatnya telah terjadi percampuran atau sinkritisme dengan agama-agama dari luar Jepang, namun orang Jepang tidak mengambil pusing terhadap hal tersebut. Dari hal tersebut dapat kita pahami bahwa kepercayaan rakyat Jepang merupakan suatu sistem kepercayaan yang hanya orang Jepang dan di tanah Jepang saja yang mengerti dan mempercayainya walaupun memang terjadi sinkritisme tetapi warna dari Shinto dan tradisi Jepang tetap terjaga.

\section{KERANGKA TEORI / TINJAUAN PUSTAKA}

Agama adalah bagian dari kebudayaan manusia. Agama biasanya didefinisikan sebagai upacaraupacara vertikal antara manusia dan Tuhannya. Pandangan seperti ini dipengaruhi oleh pandangan sosiologis yang mendikotomikan kehidupan kepada upacara ritual dengan aktivitas sehari-hari yang profan, antara hubungan yang vertikal dengan hubungan horizontal. Agama merupakan fenomena budaya yang berhubungan dengan yang gaib dan menyusup atau mempengaruhi ke aspek-aspek budaya yang lain seperti gaya hidup, seni, ekonomi, teknologi, politik dan lainnya. Sementara Victor Turner seorang antropolog mengatakan bahwa, keyakinan religius dan praktek-prakteknya nampak dari ritus-ritus yang diadakan oleh suatu masyarakat. Ritus-ritus yang dilakukan itu mendorong orang-orang untuk melakukan dan mentaati tatanan sosial tertentu. Dengan kata lain ritus-ritus memberikan motivasi dan nilai-nilai pada tingkat yang paling dalam. Dalam ritus manusia mengungkapkan apa yang menggerakkan mereka (Victor Turner; The ritual Prosess: hal.191). Dari pernyataan Turner ini, dapat dipahami bahwa keyakinan religius dan praktek-prakteknya tampak dari upacara dan ritus-ritus yang diadakan oleh suatu masyarakat. Hal ini dapat diasumsikan bahwa, walaupun dikatakan orang Jepang tidak peduli terhadap agama namun, pada kenyataannya dapat dikatakan amat religius. Orang Jepang menghormati keberadaan agama-agama yang ada dan tergolong paling banyak di dunia, jarang terdengar atau terjadi pertentangan yang disebabkan oleh perbedaan agama.

Mengenai keberadaan agama-agama di Jepang Harumi Befu seorang antropolog (1981:95-96) mengatakan bahwa agama di Jepang adalah merupakan gabungan antara kepercayaan "primitif" yang kemungkinan tidak bisa dikategorikan kedalam pengertian agama dalam pandangan agama-agama samawi.

Seperti diantara beberapa agama yang dianut di Jepang, Shinto adalah yang paling tua berbeda dengan agama-agama yang lainnya (Budha, Kon $\mathrm{Fu}$ Tsu, Katolik, Protestan, Islam dan lainnya), tidak diketahui kapan Shinto lahir atau muncul di Jepang. Shinto dikatakan konon mirip dengan kepercayaan Tao di Cina, yang juga diperkenalkan di Jepang bersamaan dengan Konfusianisme. Taoisme adalah didasarkan keyakinan pada tenaga-tenaga gaib yang ada di alam semesta yang menjadi salah satu landasan terbentuknya kepercayaan rakyat (folk beliefts) di Jepang. Sementara Befu, (1981:94-95) juga mengatakan bahwa Konfusianisme adalah sebuah ajaran agama selain filsafat moral. Setelah masuk ke Jepang unsur-unsur keagamaannya menipis, yang terus bertahan adalah aspek sekulernya seperti falsafah kehidupan dalam etika yang mengatur hubungan antar manusia dan pemerintahan dalam satu negara. Di Jepang pemikiran konfusianisme dipelajari hanya di kalangan samurai yang pada abad ke 16 tergolong sebagai golongan minoritas di dalam masyarakat saat itu. Kemudian di awal Meiji (1868) pada 
pertengahan abad 18 penyebarannya secara meluas ke semua lapisan masyarakat sebagai aturan moral atau etika.

Sikap orang Jepang terhadap agama dan ajaran yang berasal dari luar Jepang pada dasarnya tidak ada pertentangan. Karakter dan orientasi keagamaan mereka tidak sama dengan orang Barat atau orang-orang yang memiliki kepercayaan pada agama-agama Samawi. Bahwa orang Jepang mengangap agama itu bukanlah suatu yang perlu disampaikan kepada orang lain sifatnya tertutup individual bahkan eksklusif.

Melalui pendekatan Befu dan Turner akan dicoba melihat fenomena keagamaan dalam kehidupan orang Jepang.

\section{METODE PENELITIAN}

Penelitian ini merupakan penelitian kualitatif dengan menggunakan metode deskriptif analisis, yaitu dengan memaparkan dan menganalisa data yang diperoleh dari berbagai sumber berupa yang didapat dalam penelitian ini melalui data literatur dan keterlibatan. secara tidak langsung dari peneliti dalam kehidupan keagamaan orang Jepang. Adapun ketika mendiskripsikan dan menganalisa data penelitian ini penulis menfokuskan pada halhal sebagai berikut:

1) Bagaimana karakter agama-agama di Jepang?

2) Bagaimanakah fungsi agama-agama yang memiliki ikatan tadisi dalam kebudayaan penggunaan dalam kehidupan orang Jepang?

\section{HASIL ANALISIS}

Selama ini di kalangan cendikiawan Jepang sering mengemukakan bahwa bangsa Jepang termasuk negara yang atheistik, tidak religius bahkan areligius dan sangat materialistik. Namun dalam pandangan beberapa tokoh Islam di Indonesia bahwa pendapat tersebut dilihat dari sudut formal keagamaan yang monotheistik semata, sedangkan rasa keagamaan ditentukan dan ditunjukan dengan perbuatan atau kegiatan.

Seperti yang dapat terlihat dalam kehidupan orang Jepang yang amat menghargai lingkungan, menjaga dan menghormati alamnya (shizenkan) adalah ungkapan dari rasa keagamaan yang amat mendalam. Dari data literatur banyak ditemukan pendapat yang dapat diasumsikan bahwa Orang
Jepang amat menghargai dan menjaga keharmonisan hubungan manusia dengan manusia dalm berbagai aspek, hal tersebut membawa Jepang terlihat sebagai negara yang amat religius dari berbagai aspek. ${ }^{3}$ Kadang dengan mudahnya orang berpendapat bahwa orang Jepang lebih Islami dari pada orang Islam sendiri. Dalam arti apabila dibandingkan rasa keagamaan orang Jepang pada umumnya dengan rasa suatu bangsa yang keagamaannya monotheistik, sukar dikatakan bahwa orang Jepang tidak religius. Selain itu terdapat kecenderungan yang mengatakan bahwa orang Jepang lebih religius dari bangsa lain, termasuk dari negara-negara yang agamanya monotheistikpun beranggapan demikian.

Sementara itu pada kenyataannya orang Jepang memaknai agama dalam kehidupannya sebagai tradisi yang dijaga dan dilestarikan secara turun menurun. Dalam kehidupannya walaupun seringkali dikatakan sebagai atheis atau tidak percaya kepada satu dewa atau satu Tuhan juga orang Jepang dapat dikatakan polytheisme, seperti telah dijelaskan diatas pada kenyataannya orang Jepang amat religius.

Dari data literatur terungkap bahwa dalam sejarah agama-agama yang cukup panjang, Budha di Jepang memiliki kedudukan yang sama dengan Shinto, demikian pula untuk agama-agama yang lainnya juga memiliki kebebasan bergerak. Dari sejarah agama yang panjang ini dapat diketahui bahwa terjadi harmoni atau wa dalam keyakinan agama dan kepercayaan agama, karena orang Jepang dapat mendudukkan agama sebagai bagian dari tradisi yang sifatnya berkelompok ataupun individual.

Selain itu dalam agama rakyat Shinto dan Budha juga memiliki aliran-aliran yang melahirkan agama baru dan lainnya yang juga memiliki kedudukan dalam kehidupan orrang Jepang sesuai dengan kebutuhannya. Dalam pandangan orang Jepang apabila Shinto dan Budha dibandingkan maka dapat diakui bahwa agama Budha telah memperdalam dan memperhalus Shinto.

Sedangkan Shinto sebagai adalah satu kepercayaan rakyat yang yang turun menurun memiliki keyakinan bahwa alam semesta ini merupakan tempat berdiamnya para “kami gami “神々 atau para dewa. Sehingga ada kewajiban untuk menjaga

\footnotetext{
${ }^{3}$ Hori Ichiro, 1989 “, : DeVos A.Goerge and Takao Sofue, 1986
} 
dan menghormati alam semesta 自然感 atau shizenkan. ${ }^{4}$ Terdapat suatu kesepakatan bersama bahwa setiap jinja juga dipercayai sebagai tempat tinggal kami. Dengan demikian tiap jinja didiami oleh kami tertentu yang disembah oleh orang Jepang sesuai dengan fungsi dan kebutuhan yang sifatnya duniawi. Selain itu juga terdapat angapan bahwa selain jinja juga benda-benda yang berasal dari alam semesta dianggap sebagai tempat atau simbol bersemayamnya para dewa.

Selanjutnya, dengan masuknya Budha ke Jepang, dan setelah melalui penolakan dan pergulatan yang cukup panjang diantara Shinto dan Budha pada akhirnya lahirlah perpaduan yang serasi di antara dewa-dewa Shinto dan Budha yaitu Shinbutsu Shugo. Perpaduan tersebut berupa Buddha yang dianggap sebagai perwujudan atau manifestasi dari "kami" atau sebaliknya. Berdasarkan hal tersebut mungkin bisa dijadikan satu pegangan kenapa orang Jepang pergi ke Jinja atau kuil Shinto dan juga ke otera atau kuil Budha secara bersamaan. Hal-hal tersebut merupakan fenomena dari keagamaan di Jepang hingga sekarang.

Setelah Perang Dunia ke II, di Jepang banyak lahir agama-agama Baru (Shinshukkyo) walaupun sebenarnya bukan agama baru, karena pada hakekatnya agama-agama tersebut adalah denomination atau aliran dari Buddha dan Shinto. Agama-agama baru tersebut mendapat sambutan dari masyarakat Jepang karena orang Jepang menerima agama-agama baru tersebut tanpa paksaan. Bahwa di Jepang bukan saja terbuka untuk segala agama , namun tidak ada penghalang apapun untuk setiap kegiatan agama. Agama-agama baru mengisi kekosongan itu.

Pada hakekatnya kehidupan budaya dan tradisi orang Jepang adalah Shinto dan Budha. Pemerintah Jepang memberikan kebebasan beragama yang amat penuh kepada rakyatnya. Hal inilah juga yang menyebabkan agama-agama baru atau shinshukyo dapat berkembang dan menjamur. Menariknya munculnya Shinshukyo selain Budha dan Shinto didasarkan sinkritisme agama-agama seperti Kristen, Katolik, bahkan mungkin juga ajaran Sikh dan agama Islam juga dipraktekkan dalam kehidupan mereka. Selain itu Kon Fu Tsu juga memiliki fungsi yang amat penting dalam kebudayaan orang Jepang terutama dalam ajaran moral ketimbang agama. Dari data literatur dapatkan diasumsikan bahwa karakteristik dan

\footnotetext{
${ }^{4}$ Hori Ichiro , ibid P. 68
}

orientasi orang Jepang amat berbeda dengan agama monotheistik karena orang Jepang mengangap bahwa agama bukanlah suatu yang penting dalam kehidupan. Adapun sikap tersebut antara lain:

1) Orang Jepang yang sama akan menyembah atau menghormati dewa-dewa dari agama yang berbeda tanpa rasa yang bertentangan. Sebagai contoh: Di rumah orang Jepang ada Butsudan (altar Budha) dan Kamidana (altar Shinto) dan mungkin juga mereka meletakan salib Yesus, patung Bunda Maria atau simbol-simbol agama lainnya.

2) Konsep keagamaan orang Jepang mengenai dewa dapat terdiri dari agama-agama yang berbeda.

3) Ada tempat pemujaan yang meletakkan simbol-simbol dewa-dewa dari agama yang berbeda.

\section{KESIMPULAN}

Di negara-negara liberal, menganut lebih dari satu agama atau tidak memeluk agama sama sekali adalah kebebasan individu. Dari penelitian ini didapatkan kesimpulan bahwa agama yang berkembang di tengah masyarakat Jepang adalah pilihan yang terbuka untuk dipilih oleh individu dan kelompok masyarakat berdasarkan selera dan kebutuhan masing-masing, karena agama yang dianut oleh masyarakat Jepang adalah untuk memenuhi kebutuhan yang sesuai dengan kepentingan mereka sendiri. Oleh karena itu sikap mereka cenderung sekuler apabila dilihat dari penganut agama-agama monotheistik.

Sementara orang Jepang tetap menjaga dan melestarikan Shinto dan dan kepercayaan rakyat mereka sebagai tradisi secara turun menurun. Pada saat-saat tertentu orang Jepang selalu melakukan kegiatan yang berhubungan dengan keagamaan khususnya kepercayaan lokal secara teratur dalam satu tahunnya.

Hal ini memberikan suatu pegangan mengenai keagamaan orang Jepang bahwa mereka bukannya masyarakat yang areligius atau atheis dalam pandangan agama monotheistik. Seperti yang dijelaskan oleh Victor Turner bahwa keyakinan religious dan praktek-prakteknya tampak dari upacara dan ritus-ritus yang diadakan oleh suatu masyarakat.

Selanjutnya dapat dikatakan bahwa agama dianggap sebagai suatu hal yang individual dari 
masyarakat Jepang yang modern, namun juga sebagai simbol dari kelompok orang Jepang secara budaya dan tradisi dari kepercayaan rakyatnya. Orang Jepang bisa menjaga harmoni di lingkungan kehidupan mereka walaupun banyaknya agama yang ada disana, mereka memiliki lebih dari satu agama atau double faith.

\section{DAFTAR ACUAN/PUSTAKA}

[1] Agus Bustanuddin. Agama dalam Kehidupan Manusia. Rajawali Press. Jakarta. 2005.

[2] Befu Harumi. "Japan: An Anthropological Introduction. Tokyo Charles Tuttle Co. Bennet ., John W.\& Iwano Ishino. 1999

[3] Danandjaja James. Folklor Jepang. Grafiti Jakarta. 1997.

[4] DeVos A.Goerge and Takao Sofue, "Religion and the Family in East Asia Californian Press". Berkeley. 1986

[5] Edwin O Rieschauer."The Japanese Today: Change and Countinuity. Cambridge Massachusetts: Belknap Press of, Havard University Press. Pg. 215. 1988.
[6] Geerzt, Clifford. Kebudayaan dan Agama. Penterjemah Fransisco Budiman Hardiman. Judul Asli Interpretation of Culture. Jakarta, Kanisius. 2003

[7] Hanazono Toshimaro. Nihon Bunka To Shukyoo. Bungakubu Shukkyogaku. Tohoku Daigaku.1995.

[8] Hori Ichiro. "Folk Religion in Japan Continue and Change., Tokyo Charles Tuttle Co. 1989.

[9] Pritchard, E.E.Evans. Teori-Teori Tentang Agama Primitif. Terjemahan H.A.L. Yogyakarta. 1984.

[10] Miyake Hitoshi, 日本宗教の構造. Keio Tsushin. Tokyo. 1974.

[11] Norbeck, Edward. "Religion in Human Life". Holt Rinehart. New York. 1974.

[12] Sutrisno Mudji Ed.all. Teori-teori Kebudayaan. Penerbit Kanisius. Yogjakarta. 2005

[13] Turner, Victor. Myth and Symbol, dalam: The International Encyclopedia of Social Sciences, New York: Mac millan and Free Press, vol. $9 \& 10$. 1968.

[14] 石井研土、現代日本人の宗教 1999 年 データブック 